\title{
Effect of Rice Growth Stages and Silicon on Sheath Blight Development
}

\author{
Fabrício Á. Rodrigues, Francisco X. R. Vale, Lawrence E. Datnoff, Anne S. Prabhu, and Gaspar H. Korndörfer
}

First author: University of Florida-IFAS, Department of Plant Pathology, Gainesville 32611; second author: Department of Plant Pathology, Universidade Federal de Viçosa, Departamento de Fitopatologia, Viçosa, MG, Brazil, 36570; third author: University of Florida-IFAS, Everglades Research \& Education Center, Belle Glade 33430; fourth author: Centro Nacional de Pesquisa de Arroz e Feijão, Caixa Postal 179, Santo Antônio de Goiás, GO, Brazil, 75375; and fifth author: Universidade Federal de Uberlândia, Instituto de Ciências Agrárias, Caixa Postal 593, Uberlândia, MG, Brazil, 38400.

Accepted for publication 14 October 2002.

\begin{abstract}
Rodrigues, F. Á., Vale, F. X. R., Datnoff, L. E., Prabhu, A. S., and Korndörfer, G. H. 2003. Effect of rice growth stages and silicon on sheath blight development. Phytopathology 93:256-261.

The objective of this study was to determine the effect of silicon $(\mathrm{Si})$ and rice growth stages on tissue susceptibility to sheath blight (Rhizoctonia solani Kühn) under controlled conditions. Rice plants (cv. Rio Formoso) were grown in pots containing low-Si soil amended with $\mathrm{Si}$ at $0,0.48,0.96,1.44$, and $1.92 \mathrm{~g} \mathrm{pot}^{-1}$ and inoculated with $R$. solani at the following days after emergence: 45 (four-leaf stage), 65 (eight-leaf stage), 85 (tillering), 117 (booting), and 130 (panicle exsertion). For plants inoculated with $R$. solani at all growth stages, Si concentration in straw increased as rate of $\mathrm{Si}$ increased from 0 to $1.92 \mathrm{~g} \mathrm{pot}^{-1}$. Concentration of

rates of $\mathrm{Si}$ increased in the soil, the total number of sheath blight lesions on sheaths and total area under the relative lesion extension curve decreased at all plant growth stages. The severity of sheath blight was lower at booting and panicle exsertion stages as the rates of $\mathrm{Si}$ increased in the soil. In general, plants grown in Si-nonamended pots and inoculated with $R$. solani were more vulnerable to infection at all growth stages, but especially at 45 days after emergence. Plant dry weights for inoculated plants increased as the Si rates increased from 0 to $1.92 \mathrm{~g} \mathrm{pot}^{-1}$. The greatest dry weight increases occurred for plants inoculated at booting and panicle exsertion stages. Si fertilization is a promising method for controlling sheath blight in areas where soil is Si deficient and when cultivars that exhibit an acceptable level of resistance to sheath blight are not available for commercial use.
\end{abstract} calcium in the straw did not differ among plant growth stages. Although incubation period was not affected by the amount of Si added to the soil, this variable was shorter at booting and panicle exsertion stages. As the
Additional keywords: calcium silicate slag, host resistance, Oryzae sativa, Rhizoctonia solani.
Brazil is a major rice-producing country, with 5 million ha planted annually under upland or irrigated conditions. Sheath blight, caused by the fungus Rhizoctonia solani Kühn (Thanatephorus cucumeris (A. B. Frank) Donk), anastomosis group 1 IA (AG-1 IA) (33), is assuming economic importance among diseases of rice (Oryzae sativa L.) in Brazil. Rice cultivation recently has been extended to the states of Tocantins and Mato Grosso do Sul in Brazil, where diseases have caused major yield losses. The rotation of rice with soybean in these regions has been associated with an increased incidence of sheath blight. High rates of nitrogen fertilizer, early-season planting, double cropping, high plant density per unit area, and planting of early maturing, short-stature, hightillering, compact, susceptible cultivars are factors responsible for the increase in sheath blight in most rice-growing regions worldwide $(5,25,34,39)$.

Strategies to control sheath blight are limited because cultivars with complete resistance are not currently available (26). Development of cultivars with a high level of partial resistance to sheath blight has been slow because of the wide host range of the pathogen and the lack of an adequate knowledge of the diseaseyield loss relationship $(13,34)$. Additionally, there is considerable variability in disease development from the influence of many environmental effects and host characteristics $(25,39)$. In Brazil, rice cultivars that exhibit an acceptable level of resistance to sheath blight are not commercially available. Even though control

Corresponding author: L. E. Datnoff; E-mail address: ledatnoff@ifas.ufl.edu

Publication no. P-2002-1216-02R

(c) 2003 The American Phytopathological Society strategies for sheath blight have centered around the use of foliar fungicides (10), their use is limited due to perceived environmental problems, potential risk of emergence of pathogen population that become resistant, and expense. Many cultural and biological control methods have been investigated to minimize the intensity of sheath blight $(1,4,30,38,47)$.

Silicon ( $\mathrm{Si}$ ) fertilization may offer a viable method to control sheath blight, especially where soils are low or limiting in plantavailable Si. Some economically important diseases in rice, such as blast (Magnaporthe grisea (Hebert) Barr), brown spot (Cochliobolus miyabeanus (Ito \& Kuribayashi in Ito) Drechs. ex Dastur), stem rot (M. salvinii Cattaneo), leaf scald (Monographella albescens Theum), and grain discoloration have been reduced by Si application $(6-9,20,40,48)$. According to Mathai et al. (28), application of Si resulted in reduced severity of sheath blight even though the difference in disease severity between the high and low rates of $\mathrm{Si}$ was not statistically significant. The effect of Si on reducing sheath blight severity was shown to be greater in irrigated indica rice genotypes compared with japonica upland rice genotypes and intermediate groups (48). Si reduced the intensity of sheath blight on susceptible and moderately susceptible U.S. rice cultivars to levels comparable to those of cultivars highly or partially resistant to sheath blight and not amended with Si (35). For more effective management of sheath blight, it is necessary to determine plant growth stages that are most vulnerable to infection. Symptoms of sheath blight generally do not appear under field conditions until plants have reached the maximum tillering stage. At this growth stage, high humidity is maintained within the crop canopy and, consequently, contributes to favorable disease development $(34,39)$. In contrast, Valdez $(45)$ 
observed that rice is susceptible to infection by $R$. solani at all growth stages, but especially in the vegetative stage. The literature is conflicting about which is the most susceptible rice growth stage for sheath blight infection and reliable information is not available on the effect of $\mathrm{Si}$ on sheath blight intensity at different host growth stages. Consequently, the current study was undertaken to investigate the effects of $\mathrm{Si}$ and rice growth stages on tissue susceptibility to sheath blight under controlled conditions. A portion of this study was previously reported (36).

\section{MATERIALS AND METHODS}

Two five-by-five factorial experiments, consisting of five rice growth stages and five Si rates, were arranged in a randomized design with three replications in each experiment. Experiments were conducted under controlled conditions from January to July 1998 at the Federal University of Viçosa, Viçosa, Minas Gerais, Brazil. All experiments were set in an Si-deficient typic acrustox soil, with plant-available $\mathrm{Si}$ at $14.6 \mathrm{mg} \mathrm{dm}^{-3}$ collected at a depth of 0 to $20 \mathrm{~cm}$ in the 'Triângulo Mineiro' area. Plastic pots were each filled with $2 \mathrm{~kg}$ of air dried, sieved $(5 \mathrm{~mm})$ soil. Wollastonite, used as the source of $\mathrm{Si},\left(\mathrm{CaSiO}_{3}\right.$; Vansil, EW-20, Ipiranga Chemical Co., São Paulo, Brazil) is composed of $24.3 \% \mathrm{Si}$ and $42.1 \%$ calcium $(\mathrm{Ca})$. Soil was mixed with wollastonite to obtain equivalent rates of elemental $\mathrm{Si}$ at $0,0.48,0.96,1.44$, or $1.92 \mathrm{~g}$ pot $^{-1}$. Dolomitic lime was added to pots treated with $0,0.48,0.96$, or $1.44 \mathrm{~g}$ of $\mathrm{Si}$ to equilibrate the amount of $\mathrm{Ca}$ present in these treatments with the treatment that contained $1.92 \mathrm{~g}$ of Si. Pots with $1.44 \mathrm{~g}$ of $\mathrm{Si}$ received $1.44 \mathrm{~g}$ of $\mathrm{MgCl}_{2} \cdot 6 \mathrm{H}_{2} \mathrm{O}$ and that with $1.92 \mathrm{~g}$ of Si received $2.88 \mathrm{~g}$ of $\mathrm{MgCl}_{2} \cdot 6 \mathrm{H}_{2} \mathrm{O}$, to equilibrate magnesium among treatments. Soil in each pot was incubated 60 days (moist) before sowing 8 rice seeds (cv. Rio Formoso) and fertilized with $100 \mathrm{ml}$ of a nutrient solution containing, in milligrams per kilogram of soil, $100 \mathrm{~N}, 300 \mathrm{P}, 150 \mathrm{~K}, 40 \mathrm{~S}, 0.81 \mathrm{~B}, 1.33 \mathrm{Cu}$, $1.55 \mathrm{Fe}, 3.66 \mathrm{Mn}, 0.15 \mathrm{Mo}$, and $4.00 \mathrm{Zn} \mathrm{(32).} \mathrm{At} 10$ days after emergence, each pot was thinned to two plants. No modifications were made to the pots to allow for drainage, and plants were kept under flooded conditions until the end of the experiments.

A virulent isolate of $R$. solani (AG-1 IA), obtained from symptomatic plants (cv. Metica-1) in rice fields in the state of Tocantins and provided by the National Center for Research on Rice and Beans in Brazil, was used to inoculate the plants. The isolate was maintained on acid potato dextrose agar medium (APDA). Inoculum was obtained as follows: the isolate of $R$. solani was grown on APDA and incubated for 10 days at room temperature to produce mycelia. Wooden toothpicks, $1 \mathrm{~cm}$ in length, were placed in Erlenmeyer flasks containing a shallow layer of potato broth and autoclaved. After autoclaving, 15 toothpicks and five agar plugs, $5 \mathrm{~mm}$ in diameter, obtained from the margin of an actively growing colony of $R$. solani were transferred to APDA plates. These plates were allowed to incubate for 8 days at room temperature so $R$. solani could colonize the toothpicks.

Plants were inoculated at days 45 (four-leaf stage), 65 (eightleaf stage), 85 (tillering), 117 (booting), and 130 (panicle exsertion) after seedling emergence by placing a $1-\mathrm{cm}$ toothpick colonized by $R$. solani into the lowest inner sheath of the main tiller. Immediately after inoculation, all plants were transferred to a glass mist chamber. Plants were kept at $27^{\circ} \mathrm{C}$ and $90 \%$ relative humidity. The 12-h relative humidity period was maintained within this chamber with a humidifier (Herrmidifier 500 Co., Inc., Lancaster, PA). Plants received 16-h photoperiod of approximately $162 \mu \mathrm{E} \mathrm{m}^{-2} \mathrm{~s}^{-1}$ provided by cool-white fluorescent lamps.

Sheath blight progress on the inoculated and upper three sheaths of the main tiller from plants inoculated in all growth stages were evaluated as a ratio of lesion extension on sheaths, measured vertically $(\mathrm{cm})$, to the total sheath lengths $(\mathrm{cm})$. In experiment 1 , vertical lesion extension on sheaths was evaluated daily from 4 to
21,4 to 24,4 to 26,3 to 28 , and 3 to 25 days postinoculation with $R$. solani at the following days after seedling emergence: 45 (fourleaf stage), 65 (eight-leaf stage), 85 (tillering), 117 (booting), and 130 (panicle exsertion), respectively. In experiment 2, vertical lesion extension on sheaths was evaluated daily from 4 to 19,4 to 22,4 to 25,3 to 27 , and 3 to 26 days postinoculation with $R$. solani at the following days after seedling emergence: 45 (fourleaf stage), 65 (eight-leaf stage), 85 (tillering), 117 (booting), and 130 (panicle exsertion), respectively. Data from each sheath in each plant, replication, treatment, and experiment were used to construct the relative lesion extension curve. The area under the relative lesion extension curve (AURLEC) for each sheath in each plant, replication, treatment, and experiment was computed using the trapezoidal integration of relative lesion extension curve according to the formula proposed by Shaner and Finney (41). This was conducted over a period of 20 to 28 days postinoculation with $R$. solani, depending on the plant growth stage inoculated with $R$. solani in each experiment. The total AURLEC represented the sum of the AURLEC from four sheaths.

The severity of sheath blight was scored using a scale that ranged from 0 to 9 based on relative lesion height on the whole plant (18): $0=$ no infection, $1=$ lesions limited to lower $20 \%$ of the plant height, $3=$ lesions limited to lower 20 to $30 \%$ of the plant height, $5=$ lesions limited to lower 31 to $45 \%$ of the plant height, 7 = lesions limited to lower 46 to $65 \%$ of the plant height, and $9=$ lesions more than $65 \%$ of the plant height.

Incubation period was scored as the time, in hours, from inoculation until the appearance of the first lesion on the inoculated sheath for all growth stages. Sheath blight lesions that developed on the four sheaths of the main tiller were counted at the end of the experiments.

Plant dry weight was determined 20 to 28 days after inoculation with $R$. solani, depending on the rice growth stage in each experiment. Leaves and culms from each replication were dried and ground to pass through a 40-mesh screen with a Thomas-Wiley mill (Thomas Scientific, Swedesboro, NJ). Si in leaf and culm tissue was determined by automated colorimetric analysis on $0.1 \mathrm{~g}$ of dried and digested tissue (11). Results obtained were expressed in grams of $\mathrm{Si}$ per kilograms of plant tissue. Ca concentration (gram per kilogram) in tissue was determined after percloric digestion by atomic absorption spectrophotometry (19).

Data for each variable from the two experiments were pooled for statistical analysis because homogeneity of variances was confirmed by Bartlett's test (14). Moreover, the experiment-treatment interactions were not significant $(P \geq 0.05)$ when compared to the main effects of treatments. Data from each variable were analyzed by analysis of variance (ANOVA) using the GLM procedure of SAS (version 6.12). An equation and graphic that fit the data for each variable were generated using Table Curve 3D (SPSS, Inc., Chicago).

\section{RESULTS AND DISCUSSION}

Rice growth stages and rates of Si had significant effects $(P<$ $0.05)$ on the severity of sheath blight, total area under the relative lesion extension curve, total number of sheath blight lesions, plant dry weight, and Si concentration in the straw (Table 1). The incubation period was affected $(P<0.05)$ only by rice growth stages. The interaction between rice growth stages and rates of $\mathrm{Si}$ was only significant $(P<0.05)$ for severity of sheath blight (Table 1$)$.

The concentration of $\mathrm{Si}$ in the straw increased as rates of $\mathrm{Si}$ increased from 0 to $1.92 \mathrm{~g} \mathrm{pot}^{-1}$ (Fig. 1). Concentration of Si was greatest in plants inoculated with $R$. solani at 45 days after emergence (four-leaf stage), and decreased sharply as plants grew older (booting and panicle exsertion stages). The greater concentration of $\mathrm{Si}$ in tissue from plants inoculated with $R$. solani at 45 days after emergence (four-leaf stage) was from the reduced dry matter production as a result of the high intensity of sheath 
blight. Silicon is classified as an immobile element and is not retranslocated upon deposition as opal, which represents more than $90 \%$ of Si present in the plant tissue (24). Ca concentration in rice straw ranged from 2.65 to $3.35 \mathrm{~g} \mathrm{~kg}^{-1}$ among plant growth stages inoculated with $R$. solani with no significant difference $(P \geq 0.05)$ among them. Ca protects the middle lamella of host cell walls against enzymes produced by some pathogens (16). However, in this study, the level of $\mathrm{Ca}$ was carefully equilibrated in all treatments for each experiment so that only variations in $\mathrm{Si}$ levels could account for the difference in disease intensity. Datnoff et al. (7) analyzed leaf samples from Si-treated plots and found $\mathrm{Si}$, but not $\mathrm{Ca}$, to increase as calcium silicate fertilization was increased. Silicon has been reported to be the only element that has increased significantly in plant tissue of rice grown over a 3 -year period in organic soil amended with calcium silicate slag (43). Uptake of Si also may depress the absorption of $\mathrm{Ca}$ by the rice plant, and this results in a decrease of the amount of $\mathrm{Ca}$ accumulated in shoots (27).

The incubation period for sheath blight development ranged from 48 to $96 \mathrm{~h}$ regardless of the rice growth stage inoculated with $R$. solani. However, plants inoculated at 45 (four-leaf stage) and 65 (eight-leaf stage) days after emergence showed the longest incubation period, which decreased sharply for plants inoculated at day 117 (booting), and day 130 (panicle exsertion) after emergence (Fig. 2). As reported by Kozaka (22), 5- to 6-week-old leaf sheaths were more susceptible than 2- to 3-week-old sheaths. For plants inoculated with $R$. solani at all growth stages, there was no significant effect of $\mathrm{Si}$ rates on incubation period. Considering that $R$. solani has the capacity to penetrate through stomatal openings (34), this may have favored the early appearance of the first lesion on inoculated sheaths because inoculum was placed within the inner sheath. Stomatal invasion seldom occurs on the outer surface of the sheath, but is quite common on the inner surface (13). Seebold et al. (40) did not find significant differences in the incubation period of Magnaporthe grisea among susceptible and partially resistant rice cultivars amended with $\mathrm{Si}$; however, the incubation period of a resistant cultivar was significantly longer than for the other cultivars.

The total number of sheath blight lesions was higher on rice plants grown in pots without $\mathrm{Si}$ amendment and inoculated at 85 (tillering) and 117 (booting) days after emergence (Fig. 3). The number of sheath blight lesions was somewhat less on plants inoculated at 45 (four-leaf stage) and 65 (eight-leaf stage) days after emergence, and slightly less on plants inoculated at days 85 (tillering), 117 (booting), and 130 (panicle exsertion) after emergence as the Si rates ranged from 0 to $1.92 \mathrm{~g} \mathrm{pot}^{-1}$ (Fig. 3).

Plants grown in soil not amended with $\mathrm{Si}$, and inoculated at 85 (tillering) and 117 (booting) days after emergence, showed the greatest total area under the relative lesion extension curve (TAURLEC) (Fig. 4). Plants inoculated with $R$. solani at 45 (fourleaf stage) and 65 (eight-leaf stage) days after emergence and grown at the highest rate of $\mathrm{Si}$ exhibited the lowest TAURLEC compared with plants inoculated at day 117 (booting) and day 130 (panicle exsertion). Additionally, plants inoculated at 85 (tillering) and 117 (booting) days after emergence showed lower values for TAURLEC as the rates of Si ranged from 0 to $1.92 \mathrm{~g} \mathrm{pot}^{-1}$ (Fig. 4).

The exact mechanism or mechanisms by which Si reduces the intensity of rice sheath blight is still, to date, unknown. Siliconmediated resistance to rice blast has been associated with an increased in the density of silicified cells in the epidermis or the presence of a cuticle-silica double layer formed upon deposition and polymerization of silicic acid beneath the cuticle $(34,49)$. This physical barrier created after Si deposition and polymerization on leaf sheath might have affected the penetration (lower number of lesions) and colonization (decrease in vertical lesion expansion over time) by $R$. solani. Another possibility is that $\mathrm{Si}$ also may enhance rice resistance to sheath blight by stimulating plants to react more rapidly and efficiently to infection. In cucumber, there is clear evidence that $\mathrm{Si}$ mediates a number of cell defense reactions that confer protection against Pythium ultimum and Sphaerotheca fuliginea, such as the accumulation of phenolic compounds and a significant increase in chitinase, $\beta$-1,3-glucanase, peroxidase, phenylalanine ammonia-lyase, and polyphenoloxidase activities $(2,12,29)$. Zeyen et al. (51) demonstrated that soluble Si was present in considerable amounts during and immediately following papilla deposition in barley epidermal cells

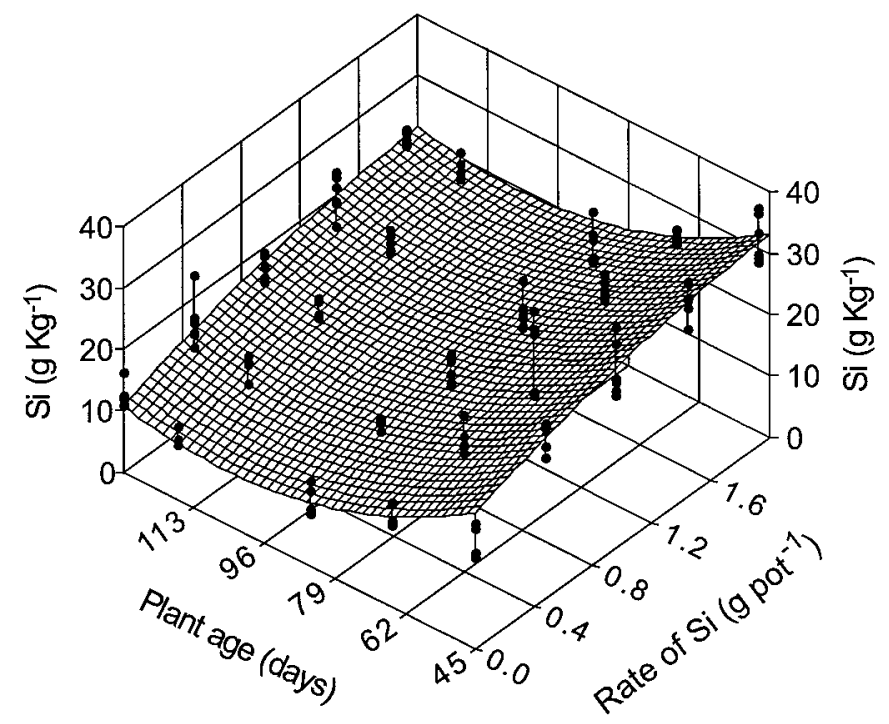

Fig. 1. Effect of rice growth stages and rates of silicon $(\mathrm{Si})$ on concentration of $\mathrm{Si}$ in the straw. The equation for the response surface is $z=49.68+$ $9.06 x-1.81 x^{2}-0.768 y+0.00351447 y^{2}, R^{2}=0.89$, where $z=\mathrm{Si}\left(\mathrm{g} \mathrm{kg}^{-1}\right), x=$ rate of $\mathrm{Si}\left(\mathrm{g} \mathrm{pot}^{-1}\right), y=$ plant age (days), and $R^{2}=$ coefficient of determination. Dots connected by a vertical line represent the six replications from the pooled experiments.

TABLE 1. Analysis of variance of the effect of rice growth stages (GS) and rates of silicon (Si) on six disease and plant components

\begin{tabular}{|c|c|c|c|c|c|c|c|}
\hline \multirow[b]{2}{*}{$\begin{array}{l}\text { Source of } \\
\text { variation }\end{array}$} & \multirow[b]{2}{*}{ df } & \multicolumn{6}{|c|}{ F values ${ }^{a}$} \\
\hline & & Incubation period & $\begin{array}{c}\text { Severity of } \\
\text { sheath blight }^{\mathrm{b}}\end{array}$ & $\begin{array}{c}\text { Total area under the relative } \\
\text { lesion extension curve }{ }^{\mathrm{c}}\end{array}$ & $\begin{array}{c}\text { Total number of } \\
\text { sheath blight lesions }\end{array}$ & $\begin{array}{l}\text { Plant dry } \\
\text { weight }\end{array}$ & $\begin{array}{c}\text { Silicon concentration } \\
\text { in straw }\end{array}$ \\
\hline GS & 4 & $24.55^{* *}$ & $25.78^{* *}$ & $4.06^{* *}$ & $18.81^{\text {** }}$ & $16.23^{* *}$ & $73.39^{* *}$ \\
\hline $\mathrm{Si}$ & 4 & $0.30^{\mathrm{ns}}$ & $40.44^{* *}$ & $2.98^{*}$ & $12.89^{* *}$ & $70.38^{* *}$ & $44.29^{* *}$ \\
\hline $\mathrm{GS} \times \mathrm{Si}$ & 16 & $0.75^{\mathrm{ns}}$ & $3.34^{* *}$ & $1.00^{\mathrm{ns}}$ & $1.67^{\mathrm{ns}}$ & $1.81^{\mathrm{ns}}$ & $1.56^{\mathrm{ns}}$ \\
\hline
\end{tabular}

${ }^{\text {a }}$ Levels of probability: $\mathrm{ns}=$ nonsignificant, $*=0.05$, and $* *=0.01$.

b The severity of sheath blight was scored using a scale that ranged from 0 to 9 based on relative lesion height on the whole plant.

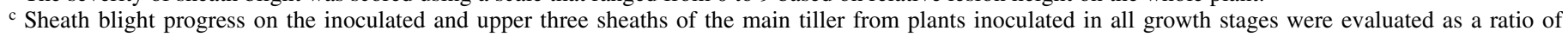
vertical lesion extension $(\mathrm{cm})$ to sheath length $(\mathrm{cm})$. The relative lesion extension curve was constructed from plant, sheath, replication, treatment, and experiment data. The area under the relative lesion extension curve (AURLEC) for each sheath in each plant, replication, treatment, and experiment was computed using the trapezoidal integration of relative lesion extension curve in a period of time ranging from 20 to 28 days postinoculation with Rhizoctonia solani, depending on the plant growth stage in each experiment. The total AURLEC represented the sum of the AURLEC from four sheaths. 
infected by Erysiphe graminis. This finding suggests that Si plays more than a passive role during attempted fungal penetration.

The shorter length of sheaths on plants inoculated with $R$. solani at 45 (four-leaf stage) and 65 (eight-leaf stage) days after emergence might have affected the number of lesions formed on those sheaths. Increased thickness of epicuticular wax appears to be correlated with resistance to sheath blight and with decreased production of lobate appressoria and infection cushions by $R$. solani (15). Rodrigues et al. (35) considered reduction in lesion extension to be the most important component of resistance to sheath blight, especially in moderately susceptible and susceptible U.S. rice cultivars. Volk et al. (46) hypothesized that lesion size of rice blast could be reduced by organosilicon compounds in the walls of epidermal cells. Inanaga et al. (17) later showed that silicic acid may compete with $\mathrm{Ca}$ for binding sites on the cell wall after some complexes are formed with polyhydric alcohols, organic acids, lignin, and phenol-carbohydrate.

Plants grown in pots without $\mathrm{Si}$ amendments and inoculated with $R$. solani at any growth stage exhibited the highest values for severity of sheath blight (Fig. 5). Severity of sheath blight reached lower values on plants inoculated with $R$. solani at 117 (booting) and 130 (panicle exsertion) days after emergence as the rates of $\mathrm{Si}$ increased from 0 to $1.92 \mathrm{~g} \mathrm{pot}^{-1}$.

The information available in the literature on which rice growth stage is the most susceptible to infection by $R$. solani is somewhat contradictory. A sheath blight epidemic occurs rapidly in the early heading and grain filling growth stages (39). Young plants seem to be more resistant than older plants and the greatest susceptibility

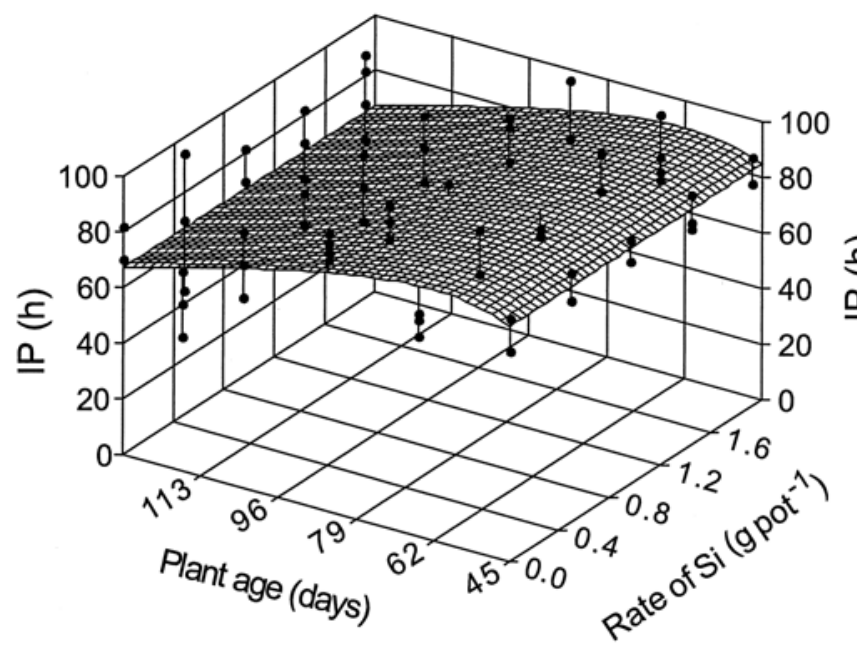

Fig. 2. Effect of rice growth stages and rates of silicon $(\mathrm{Si})$ on incubation period (IP). The equation for the response surface is $z=863.05-$ $141.81 \operatorname{Ln}(y)-2818.30 \operatorname{Ln}(y / y), R^{2}=0.65$, where $z=\mathrm{IP}(\mathrm{h}), y=$ plant age (days), and $R^{2}=$ coefficient of determination. Dots connected by a vertical line represent the six replications from the pooled experiments.

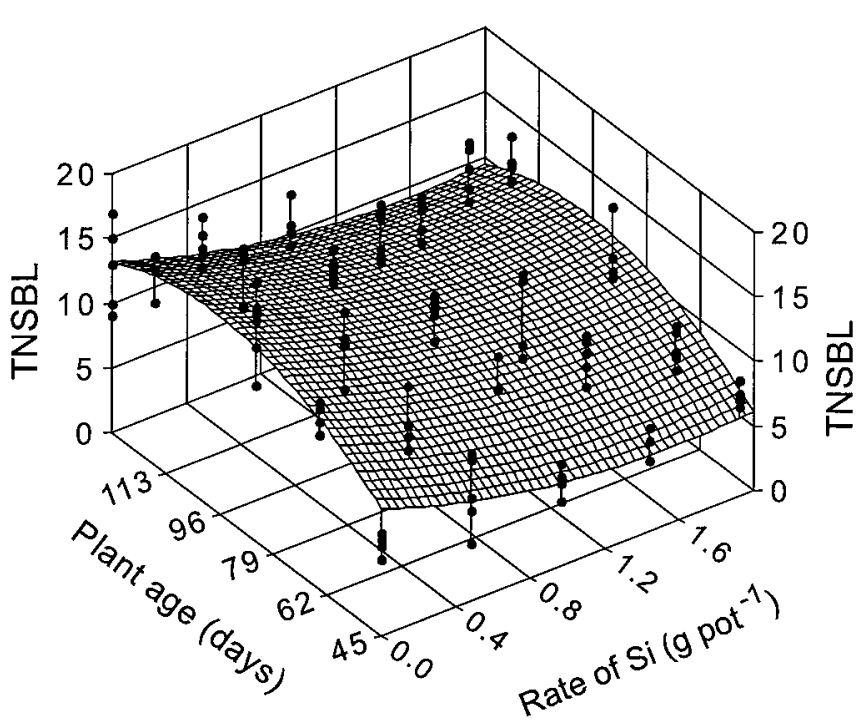

Fig. 3. Effect of rice growth stages and rates of $\mathrm{Si}$ on total number of sheath blight lesions (TNSBL) on sheaths. The equation for the response surface is $z=-3.53-5.14 x+1.64 x^{2}+0.3877 y-0.00199 y^{2}, R^{2}=0.69$, where $z=$ TNSBL, $x=$ rate of Si $\left(\mathrm{g} \mathrm{pot}^{-1}\right), y=$ plant age (days), and $R^{2}=$ coefficient of determination. Dots connected by a vertical line represent the six replications from the pooled experiments.

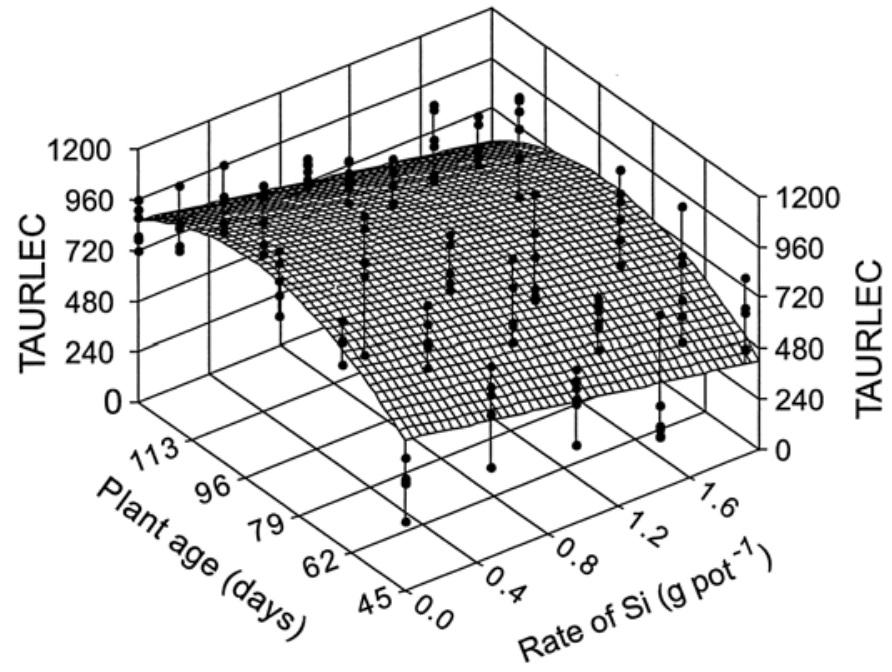

Fig. 4. Effect of rice growth stages and rates of silicon $(\mathrm{Si})$ on total area under the relative lesion extension curve (TAURLEC). The equation for the response surface is $z=-192.99-149.20 x+26.76 y-0.14322 y^{2}, R^{2}=0.70$, where $z=$ TAURLEC, $x=$ rate of $\mathrm{Si}\left(\mathrm{g} \mathrm{pot}^{-1}\right), y=$ plant age (days), and $R^{2}=$ coefficient of determination. Dots connected by a vertical line represent the six replications from the pooled experiments.

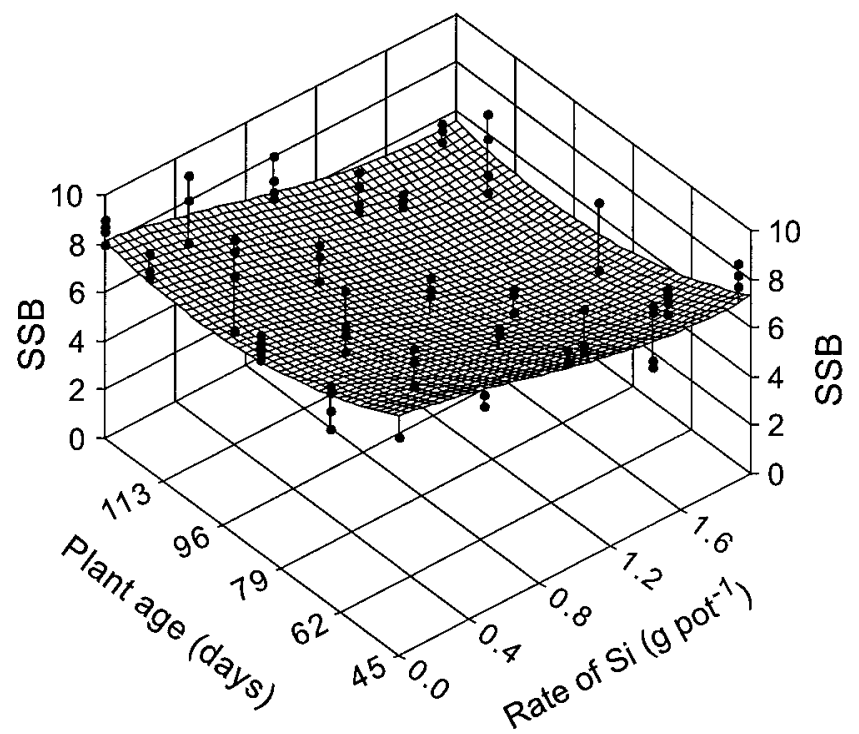

Fig. 5. Effect of rice growth stages and rates of silicon (Si) on severity of sheath blight (SSB). The equation for the response surface is $z=14.79-$ $1.11 x+1.13 x^{2}+0.52 x^{3}-0.139284 y+0.00069 y^{2}+0.0000001325 y^{3}, R^{2}=$ 0.78 , where $z=\mathrm{SSB}, x=$ rate of $\mathrm{Si}\left(\mathrm{g} \mathrm{pot}^{-1}\right), y=$ plant age (days), and $R^{2}=$ coefficient of determination. Dots connected by a vertical line represent the six replications from the pooled experiments. 
occurs at panicle emergence (34). Seedlings may be infected easily when in contact with sclerotia produced by the fungus (13). Lakpale et al. (23) observed that transplanted seedlings 20 and 30 days old showed the highest severity of sheath blight compared with seedlings 40, 50, and 60 days old. The authors also reported that the maximum tillering stage was more suitable for disease development compared with booting and milk stages. Similarly, Roy (37) observed that $R$. solani caused maximum disease and, consequently, yield loss on rice plants inoculated at the maximum tillering stage, less at exsertion of tillering, and the least at booting stage. Yoshimera and Nishizawa (50) also found that inoculation with $R$. solani at the maximum tillering stage was the most suitable for varietal testing. In contrast, Sharma et al. (42) observed that rice was more susceptible to sheath blight at booting and flowering stages than at tillering and panicle exsertion stages. $\mathrm{Cu}$ et al. (3) demonstrated that the incidence of sheath blight was great when plants were inoculated at panicle exsertion, booting, or flowering stages, and significantly lower at tillering and grainfilling stages. Tsai (44) inoculated, under controlled conditions, rice plants at different stages of growth to determine the relationship between intensity of sheath blight and yield losses. Plants inoculated at 15 days after sowing were quickly killed by $R$. solani. Sheath blight intensity also reached high values at stages of maximum tillering and booting. In this study, however, we observed that rice plants grown in pots without $\mathrm{Si}$ amendment and inoculated at any growth stage, but particularly at 45 (four-leaf stage) days after emergence, exhibited the highest values for disease intensity as a whole when compared with Si-treated plants. Unlike the controlled conditions in a greenhouse, in the field the rice growth stage most susceptible to sheath blight may vary markedly by climatic conditions. As reported by Kozoka (21), rice plants become more susceptible to sheath blight as they grow older due to an adequate microclimate within the crop canopy which greatly affects the incidence and the damage caused by this disease.

Plant dry weight increased as the rates of Si ranged from 0 to $1.92 \mathrm{~g} \mathrm{pot}^{-1}$, and reached the highest values at 117 (booting) and 130 (panicle exsertion) days after emergence (Fig. 6). For plants grown in pots without $\mathrm{Si}$, plant dry weight increased somewhat as plants grew older, although the values were lower when compared with those obtained from plants grown at the highest $\mathrm{Si}$ rate. Increases in dry matter accumulation could be attributed to a decrease in the intensity of sheath blight by $\mathrm{Si}$ application. Infection

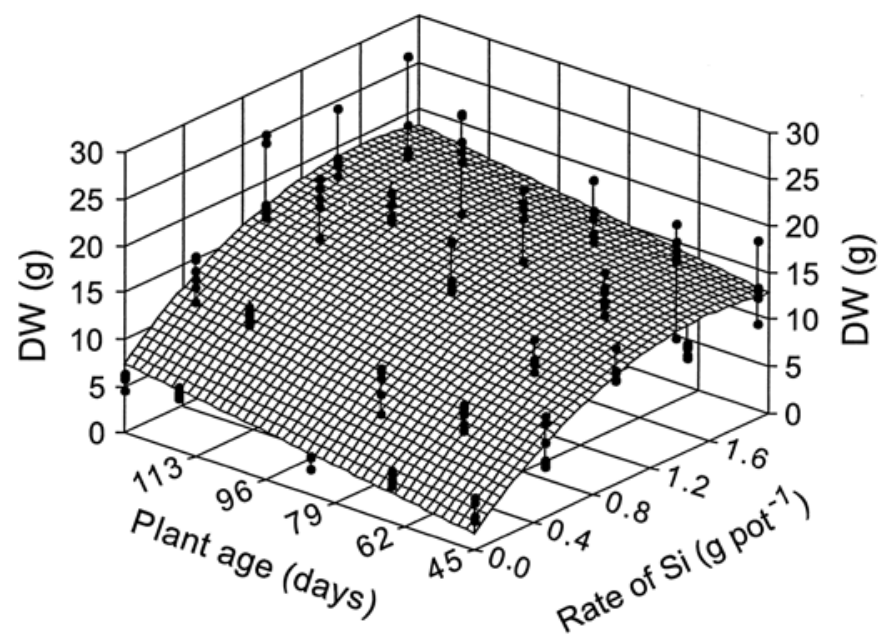

Fig. 6. Effect of rice growth stages and rates of silicon $(\mathrm{Si})$ on dry weight (DW) of two inoculated plants. The equation for the response surface is $z=$ $-1.16+14.64 x-4.56 x^{2}+0.06604 y, R^{2}=0.75$, where $z=\mathrm{DW}(\mathrm{g}), x=$ rate of Si $\left(\mathrm{g} \mathrm{pot}^{-1}\right), y=$ plant age (days), and $R^{2}=$ coefficient of determination. Dots connected by a vertical line represent the six replications from the pooled experiments. by $R$. solani in rice changes dramatically the dynamic balance of synthesis and decomposition of chlorophyll pigments on leaves and also the rate of photosynthesis (31), due to the formation of many expanding lesions on leaf sheaths and blades.

The results presented in this study provide clear evidence that Si can be used successfully to enhance the level of rice resistance to sheath blight. Fertilization with $\mathrm{Si}$ could become important in areas where soil is Si deficient and when cultivars that exhibit an acceptable level of resistance to the pathogen are not available for commercial use.

\section{ACKNOWLEDGMENTS}

This research was supported in part by the Florida Agricultural Experiment Station and approved for publication as Journal Series No. R08813. We thank CAPES for support of F. A. Rodrigues; G. F. Corrêa, A. M. A. Oliveira, and T. Davoli for their advice; and R. Berger for the review of the manuscript and suggestions for its improvement.

\section{LITERATURE CITED}

1. Belmar, S. B., Jones, R. K., and Starr, J. L. 1987. Influence of crop rotation on inoculum density of Rhizoctonia solani and sheath blight incidence in rice. Phytopathology 77:1138-1143.

2. Chérif, M., Benhamou, N., Menzies, J. G., and Bélanger, R. R. 1992. Silicon induced resistance in cucumber plants against Pythium ultimum. Physiol. Mol. Plant Pathol. 41:411-425.

3. Cu, R. M., Mew, T. W., Cassman, K. G., and Teng, P. S. 1996. Effect of sheath blight on yield in tropical, intensive rice production system. Plant Dis. 80:1103-1108.

4. Damicone, J. P., Patel, M. V., and Moore, W. F. 1993. Density of sclerotia of Rhizoctonia solani and incidence of sheath blight in rice fields in Mississippi. Plant Dis. 77:257-260.

5. Dath, A. P. 1990. Sheath Blight Disease of Rice and Its Management. Associated Publishing Company, New Delhi, India.

6. Datnoff, L. E., Deren, C. W., and Snyder, G. H. 1997. Silicon fertilization for disease management of rice in Florida. Crop Prot. 16:525-531.

7. Datnoff, L. E., Raid, R. N., Snyder, G. H., and Jones, D. B. 1991. Effect of calcium silicate on blast and brown spot intensities and yields of rice. Plant Dis. 75:729-732.

8. Datnoff, L. E., Snyder, G. H., and Deren, C. W. 1992. Influence of silicon fertilizer grades on blast and brown spot development and on rice yields. Plant Dis. 76:1011-1013.

9. Deren, C. W., Datnoff, L. E., Snyder, G. H., and Martin, F. G. 1994. Silicon concentration, disease response, and yield components of rice genotypes grown on flooded organic Histosols. Crop Sci. 34:733-737.

10. Eeckhout, E. V., Rush, M. C., and Blackwell, M. 1991. Effects of rate and timing of fungicide applications on incidence and severity of sheath blight and grain yield of rice. Plant Dis. 75:1254-1261.

11. Elliot, C. L., and Snyder, G. H. 1991. Autoclave-induced digestion for the colorimetric determination of silicon in rice straw. J. Agric. Food Chem. 39:1118-1119.

12. Fawe, A., Abou-Zaid, M., Menzies, J. G., and Bélanger, R. R. 1998. Silicon-mediated accumulation of flavonoid phytoalexins in cucumber. Phytopathology 88:396-401.

13. Gangopadhyay, S., and Chakrabarti, N. K. 1982. Sheath blight of rice. Rev. Plant Pathol. 61:451-460.

14. Gomez, K. A., and Gomez, A. A. 1994. Statistical Procedures for Agricultural Research. 2nd ed. John Wiley \& Sons, New York.

15. Groth, D. E., and Nowick, E. M. 1992. Selection for resistance to rice sheath blight through number of infection cushions and lesion type. Plant Dis. 76:721-723.

16. Huber, D. M. 1980. The role of mineral nutrition in defense. Pages 381406 in: Plant Pathology-An Advanced Treatise. How Plants Defend Themselves. Vol. 5. J. G. Horsfall and E. C. Cowling, eds. Academic Press, New York.

17. Inanaga, S., Okasaka, A., and Tanaka, S. 1995. Does silicon exist in association with organic compounds in rice plant? Soil Sci. Plant Nutr. 11:111-117.

18. IRRI. 1996. Standard Evaluation System for Rice. 4th ed. International Rice Research Institute, Manila, Philippines.

19. Johnson, C. M., and Ulrich. A. 1959. Analytical Methods for Use in Plant Analyses. University of California, Los Angeles.

20. Korndörfer, G. H., Datnoff, L. E., and Corrêa, G. F. 1999. Influence of silicon on grain discoloration of upland rice grown on four savanna soils from Brazil. J. Plant Nutr. 22:93-102.

21. Kozaka, T. 1961. Ecological studies on sheath blight of rice plants 
caused by Pellicularia sasakii (Shirai) S. Ito and its chemical control. Chugoku Agric. Res. 20:1-133.

22. Kozaka, T. 1963. Control of rice blast by cultivation practices in Japan. Pages 421-438 in: The Rice Blast Disease. Proc. Symp. IRRI. Johns Hopkins Press, Baltimore.

23. Lakpale, N., Kotasthane, A. S., Thrimurty, V. S., and Agrawal, K. C. 1996. Influence of host factors on sheath blight of rice. Indian J. Mycol. Plant Pathol. 26:193-195.

24. Lanning, F. C. 1963. Silicon in rice. J. Agric. Food Chem. 11:435-437.

25. Lee, F. N., and Rush, M. C. 1983. Rice sheath blight: A major rice disease. Plant Dis. 67:829-832.

26. Li, Z., Pinson, S. R. M., Marchetti, M. A., Stansel, J. W., and Park, W. D. 1995. Characterization of quantitative trait loci (QTLs) in cultivated rice contributing to field resistance to sheath blight (Rhizoctonia solani). Theor. Appl. Genet. 91:382-388.

27. Ma, J. F., and Takahashi, E. 1993. Interaction between calcium and silicon in water-cultured rice plants. Plant Soil 148:107-113.

28. Mathai, G., Paily, P. V., and Menon, M. R. 1977. Effect of fungicides and silica in the control of sheath blight disease of rice caused by Corticium sasakii (Shiriai). Agric. Res. J. Kerala 19:79-83.

29. Menzies, J. G., Ehret, D. L., Glass, A. D. M., and Samuels, A. L. 1991. The influence of silicon on cytological interactions between Sphaerotheca fulginea and Cucumis sativus. Physiol. Mol. Plant Pathol. 39:403414.

30. Mew, T. W., and Rosales, A. M. 1986. Bacterization of rice plants for control of sheath blight caused by Rhizoctonia solani. Phytopathology 76:1260-1264.

31. Naidu, D. V., Rao, B. S., and Murty, P. S. S. 1981. Influence of sheath blight infection on the levels of chlorophyll and ${ }^{14} \mathrm{CO}_{2}$ uptake in rice. Indian Phytopathol. 34:30-33.

32. Novais, R. F., Neves, J. C. L., and Barros, N. F. 1991. Ensaio em ambiente controlado. Pages 189-253 in: Métodos de Pesquisa em Fertilidade do Solo. A. L. Oliveira, W. E. Garrido, J. D. Araújo, and S. Lourenço, eds. EMBRAPA-SEA, Brasília, Brazil.

33. Ogoshi, A. 1987. Ecology and pathogenicity of anastomosis and intraspecific groups of Rhizoctonia solani Kühn. Annu. Rev. Phytopathol. 25:125-143.

34. Ou, S. H. 1985. Rice Diseases. 2nd ed. Commonwealth Mycological Institute, Kew, England.

35. Rodrigues, F. A, Datnoff, L. E., Korndörfer, G. H., Seebold, K. W., and Rush, M. C. 2001. Effect of silicon and host resistance on sheath blight development in rice. Plant Dis. 85:827-832.

36. Rodrigues, F. A., Vale, F. X. R., Datnoff, L. E., Prabhu, A., Korndörfer, G. H., and Zambolim, L. 2001. Influence of silicon rates and plant growth stages on rice sheath blight development. (Abstr.) Phytopathology 91(suppl.):S77.

37. Roy, A. K. 1979. Susceptibility of rice plants to sheath blight at different stages of growth. Kavaka 7:25-26.

38. Roy, A. K. 1996. Innovative methods to manage sheath blight of rice. J. Mycopathol. Res. 34:13-19.

39. Rush, M. C., and Lee, F. N. 1992. Sheath blight. Pages 22-23 in: Compendium of Rice Diseases. R. K. Webster and P. S. Gunnell, eds. The American Phytopathological Society, St. Paul, MN.

40. Seebold, K. W., Kucharek, T. A., Datnoff, L. E., Correa-Victoria, F. J., and Marchetti, M. A. 2001. The influence of silicon on components of resistance to blast in susceptible, partially resistance, and resistant cultivars of rice. Phytopathology 91:63-69.

41. Shaner, G., and Finney, R. E. 1977. The effect of nitrogen fertilization on the expression of slow-mildewing resistance in Knox wheat. Phytopathology 67:1051-1056.

42. Sharma, N. R., Teng, P. S., and Olivares, F. M. 1990. Effect of rice growth stage on sheath blight $(\mathrm{ShB})$ development and yield loss. Int. Rice Res. Newsl. 15:19-20.

43. Snyder, G. H., Jones, D. B., and Gascho, G. J. 1986. Silicon fertilization of rice on Everglades Histosols. Soil Sci. Soc. Am. J. 50:1259-1263.

44. Tsai, W. H. 1974. Assessment of yield losses due to rice sheath blight at different inoculation stages. J. Taiwan Agric. Res. 23:188-194.

45. Valdez, R. B. 1955. Sheath spot of rice. Philipp. Agric. 39:317-336.

46. Volk, R. J., Kahn, R. P., and Weintraub, R. L. 1958. Silicon content of the rice plant as a factor in influencing its resistance to infection by the rice blast fungus Piricularia oryzae. Phytopathology 48:121-178.

47. Willocquet, L., Fernandez, L., and Savary, S. 2000. Effect of various crop establishment methods practiced by Asian farmers on epidemics of rice sheath blight caused by Rhizoctonia solani. Plant Pathol. 49:346354.

48. Winslow, M. D. 1992. Silicon, disease resistance, and yield of rice genotypes under upland cultural conditions. Crop Sci. 32:1208-1213.

49. Yoshida, S. S., Ohnishi, Y., and Kitagishi, K. 1962. Histochemistry of silicon in rice plant. (III) The presence of cuticle-silica double layer in the epidermal tissue. Jpn. J. Soil Sci. Plant Nutr. 8:107-113.

50. Yoshimera, S., and Nishizawa, T. 1954. Studies on the method of testing of varietal resistance of upland rice plants caused by sheath blight, Hypochnus sasakii, Shirai Bull. Yushnu Agric. Exp. Stn. 2:361-376.

51. Zeyen, R. J., Ahlstrand, G. G., and Carver, T. L. W. 1993. X-ray microanalysis of frozen-hydrated, freeze-dried, and critical point dried leaf specimens: Determination of soluble and insoluble chemical elements at Erysiphe graminis epidermal cell papilla sites in barley isolines containing $M l-O$ and $m l-O$ alleles. Can. J. Bot. 71:284-296. 